\title{
LETTER
}

\section{Matrix metalloproteinases and their inhibitors as biomarkers of severity in sepsis}

\author{
Leonardo Lorente* ${ }^{* 1}$ María M Martín², Jordi Solé-Violán ${ }^{3}$ José Blanquer and José Antonio Páramo5 \\ See related commentary by Hoffmann et al., http://ccforum.com/content/13/6/1006
}

We read with interest the commentary by Hoffmann and colleagues [1] on our manuscript recently published in Critical Care showing that matrix metalloproteinase (MMP)-9, MMP-10 and tissue inhibitor of matrix metalloproteinases (TIMP)-1 could be new biomarkers of severity and mortality in sepsis [2]. As they stated, the lack of serial measurements of MMPs and TIMPs over clinical evolution was as a limitation of our study. Despite this limitation, our results suggest that MMPs and TIMPs may be of pathophysiological significance in sepsis.

Some clinical studies have found higher circulating levels of MMP-9 [2-4] and TIMP-1 [2,3] in septic patients than in healthy controls, and higher levels of TIMP-1 $[2,3]$ or MMP-9 [4] in nonsurviving than in surviving septic patients. Our study also reports, for the first time, that MMP-10 circulating levels are also elevated in septic patients [2]. According to the results of some in vitro studies, MMP-10 could play a role in infection, since increased MMP-10 gene transcription was observed after infective stimulation of human and mice cells.

On the other hand, we think the correlation between MMP-9, TIMP-1 and markers of coagulopathy, and the lower MMP-9/TIMP-1 ratio in nonsurviving than in surviving septic patients found in our study, may be associated with a higher prothrombotic/antifibrinolytic state, responsible for the capillary thrombosis, multiple organ dysfunction, and death.

Finally, from a therapeutic perspective, the development of modulators of MMP/TIMP activity could be used as a new class of drugs for the treatment of severe sepsis [5].

\footnotetext{
Abbreviations

MMP = matrix metalloproteinase; TIMP = tissue inhibitor of matrix metalloproteinases.
}

\footnotetext{
*Correspondence: lorentemartin@msn.com

'Intensive Care Unit, Hospital Universitario de Canarias, Ofra s/n. La Cuesta, La Laguna 38320, Santa Cruz de Tenerife, Spain
}

Full list of author information is available at the end of the article

\section{Acknowledgements}

The present study was supported, in part, by a grant from the Canary Islands Foundation for Health and Research (FUNCIS number PI 42/07) (Tenerife, Spain), by a grant from the Working Group on Infectious Diseases of the Spanish Society of Intensive Medicine, Critical Care, and Coronary Units (GTEI-SEMICYUC-2009), by funding from the Rafael Clavijo Foundation for Biomedical Research (Tenerife, Spain) and by the UTE project CIMA (University of Navarra, Spain).

\section{Author details}

'Intensive Care Unit, Hospital Universitario de Canarias, Ofra s/n. La Cuesta, La Laguna 38320, Santa Cruz de Tenerife, Spain

${ }^{2}$ Intensive Care Unit. Hospital Universitario Nuestra Señora de Candelaria. Crta del Rosario s/n. Santa Cruz de Tenerife - 38010. Spain

${ }^{3}$ Intensive Care Unit. Hospital Universitario Dr. Negrín. Barranco de la Ballena s/n. Las Palmas de Gran Canaria - 35010. Spain

${ }^{4}$ Intensive Care Unit. Hospital Clínico Universitario de Valencia. Avda. Blasco Ibáñez no17-19. Valencia - 46004. Spain

${ }^{5}$ Atherosclerosis Research Laboratory. CIMA-University of Navarra. Avda Pío XII n०55. Pamplona - 31008. Spain

\section{Competing interests}

The authors declare that they have no competing interests.

Published: 19 January 2010

\section{References}

1. Hoffmann U, Brueckmann M, Borggrefe M: Matrix metalloproteinases and their inhibitors: promising novel biomarkers in severe sepsis? Crit Care 2009, 13:1006.

2. Lorente L, Martin MM, Labarta L, Diaz C, Sole-Violan J, Blanquer J, Orbe J, Rodriguez JA, Jimenez A, Borreguero-Leon JM, Belmonte F, Medina JC, Lliminana MC, Ferrer-Aguero JM, Ferreres J, Mora ML, Lubillo S, Sanchez M, Barrios Y, Sierra A, Paramo JA: Matrix metalloproteinase-9, -10, and tissue inhibitor of matrix metalloproteinases- 1 blood levels as biomarkers of severity and mortality in sepsis. Crit Care 2009, 13:R158.

3. Hoffmann U, Bertsch T, Dvortsak E, Liebetrau C, Lang S, Liebe V, Huhle G, Borggrefe M, Brueckmann M: Matrix-metalloproteinases and their inhibitors are elevated in severe sepsis: prognostic value of TIMP-1 in severe sepsis. Scand I Infect 2006, 38:867-872.

4. Nakamura T, Ebihara I, Shimada N, Shoji H, Koide H: Modulation of plasma metalloproteinase-9 concentrations and peripheral blood monocyte mRNA levels in patients with septic shock: effect of fiber-immobilized polymyxin B treatment. Am J Med Sci 1998, 316:355-360.

5. Zhu S, Ashok M, Li J, Li W, Yang H, Wang P, Tracey KJ, Sama AE, Wang H: Spermine protects mice against lethal sepsis partly by attenuating surrogate inflammatory markers. Mol Med 2009, 15:275-282.

doi:10.1186/cc8211

Cite this article as: Lorente L, et al: Matrix metalloproteinases and their inhibitors as biomarkers of severity in sepsis. Critical Care 2010, 14:402. 